\title{
PENGAWASAN TERHADAP TRANSAKSI BISNIS E-COMMERCE DALAM MEWUJUDKAN PERLINDUNGAN KONSUMEN
}

\author{
Anak Agung Made Ayu Rai Lidya Astari, I Nyoman Putu Budiartha, Ni Made Puspasutari Ujianti \\ Fakultas Hukum Universitas Warmadewa, Denpasar-Bali, Indonesia
}

\begin{abstract}
Abstrak
E-commerce ialah suatu kegiatan jual beli yang dilakukan melalui internet dengan media elektronik. Berdasarkan hal tersebut diangkat dua permasalahan sebagai berikut: 1). Bagaimana aspek perlindungan konsumen terhadap transaksi bisnis elektronik, 2). Bagaimana pengaturan pengawasan transaksi bisnis elektronik dalam menjamin terselenggaranya hak - hak konsumen. Metode penelitian yang dilakukan dalam penyusunan penelitian ini adalah normatif dengan pendekatan perundang-undangan dan pendekatan konseptual yaitu menganalisis permasalahan yang akan dibahas melalui konsep hukum yang diambil dari beberapa buku dan literatur yang ada relevensinya dengan permasalahan. Adapun Sumber data yang dipergunakan adalah data primer yaitu melalui peraturan perundang-undangan, data sekunder yaitu menggunakan teori hukum dan para ahli, dan data tersier yaitu terkait dengan kamus hukum dan ensiklopedia. Teknik pengumpulan data melalui metode pencatatan bahan hukum serta mengumpulkan referensi yang digunakan. Analisis data menggunakan interpretasi hukum secara sistematis dan argumentasi hukum berdasarkan logika deduktif. Namun semua pemanfaatan yang ditawarkan, muncul kekhawatiran tanggungjawab perusahaan online kepada konsumen online mengingat begitu banyaknya perusahaan online. Undang- Undang Perdagangan dan Undang-Undang Perlindungan Konsumen menjadi sebuah dasar patokan dalam suatu perdagangan pada perdagangan online dan/atau dalam perdagangan konvensional. Dalam hal ini perlunya pengawasan guna meningkatkan keharmonisasian pada setiap penerapannya. Hasil penelitian menunjukkan bahwa aspek perlindungan yang di lakukan dengan cara mempertahankan hak-hak konsumen terhadap gangguang pihak lain. Agar meningkatkan kesadaran, pengetahuan, kepedulian, dan kemandirian konsumen terutama dalam memilih, menentukan dan menuntut hak-haknya sebagai konsumen. Ada beberapa asas-asas dalam perlindungan konsumen yaitu asas manfaat, asas keadilan, asas keamanan dan keselamatan, asas keseimbangan, asas kepastian hukum.
\end{abstract}

Kata kunci : E-Commerce; Pengawasan; Perlindungan konsumen

\begin{abstract}
E-commerce is a buying and selling activity carried out via the internet with electronic media. Based on this, two problems were raised as follows: 1). What are the aspects of consumer protection against electronic business transactions, 2). How to regulate the control of electronic business transactions in ensuring the implementation of consumer rights. The research method used in the preparation of this research is normative with a statutory approach and a conceptual approach, namely analyzing the problems to be discussed through legal concepts taken from several books and literature that have relevance to the problem. The data sources used are primary data, namely through statutory regulations, secondary data, namely using legal theory and experts, and tertiary data, namely related to legal dictionaries and encyclopedias. The technique of collecting data is through the method of recording legal materials and collecting references used. The data analysis used systematic legal interpretation and legal argumentation based on deductive logic. However, all the benefits that are offered, there is a concern about the responsibility of online companies to online consumers considering so many online companies. The Trade Law and the Consumer Protection Act are the basis for trading in online trading and / or in conventional trading. In this case the need for supervision in order to improve harmony in each application. The results showed that the aspect of protection was carried out by defending the rights of consumers against the disturbance of other parties. In order to increase awareness, knowledge, concern and independence of consumers, especially in choosing, determining and demanding their rights as consumers. There are several principles in consumer protection, namely the principle of benefit, the principle of justice, the principle of security and safety, the principle of balance, the principle of legal certainty.
\end{abstract}

Keywords: E-Commerce; Supervision; Consumer Protection. 


\section{PENDAHULUAN}

E-commerce merupakan suatu kegiatan jual beli melalui media internet. Dengan kemajuan teknologi yang sangat pesat maka terjadilah jual beli secara online yang dapat memudahkan para konsumen dan pelaku usaha untuk memasarkan barang dan/atau jasanya (Barkatullah, 2007; Paryadi, 2018). Tapi dibalik kemudahaan itu dapat timbulnya kecurangan yang dapat merugikan konsumen. Dalam hal ini pemerintah membuat sebuah peraturan yang dapat melindunginya. Selain UndangUndang Perlindungan Konsumen dan Undang-Undang Perdagangan menjadi acuan bagi setiap penjual perdagangan, pada perdagangan konvensional maupun perdagangan melalui sistem elektronik. Undang - Undang ITE juga sangat berperan dalam e-commerce sebab ini dilakukan menggunakan media elektronik dan dunia maya.

Ditengah globalisasi komunikasi yang semakin terpadu (global communication network) ini, internet menjadi populer dan membuat dunia semakin mengecil (shrinking the world) sekaligus memudarkan batas negara berikut kedaulatan dan tatanan masyarakatnya (Sanusi, 2010). Fungsi internet dalam kehidupan kreatif tidak hanya menjadi sumber ilmu pengetahuan namun dapat juga menjadi sumber mata pencaharian bagi setiap orang. Terdapat beberapa alasan pada pesatnya peningkatan transaksi bisnis elektronik ini antara lain, adalah karena praktis, kemudahan dalam sistem pembayaran, serta efisiensi waktu hingga banyaknya harga promo yang begitu menarik dari pedagang online. Namun segala kemudahan dan keuntungan yang ditawarkan dapat muncul kegelisahan tanggungjawab perusahaan online kepada konsumen online sebab begitu banyaknya perusahaan online yang ada di negeri ini.

Undang-Undang Perlindungan Konsumen ialah pedoman bagi penjual dan pembeli bisa menjalankan usahanya secara jujur dan tepat untuk menghindari terjadinya kerugian (Setyawati et al., 2017; Tuela, 2014). Perkembangan perlindungan hak-hak konsumen adalah kebijakan yang tertuang dalam teori Caveat Emptor konsumen dituntut harus berhati-hati dan teliti dalam melakukan traksaksi jual beli (Setyawati et al., 2017) . Asas Kepercayaan merupakan salah satu asas yang digunakan oleh para konsumen dan produsen pada penggunaan transaksi elektronik. Dalam mengantisipasi tindak pidana penipuan, pada transaksi bisnis perdangan elektronik orang atau badan usaha dibidang perdagangan harus mengisi data dan informasi secara tepat. E-commerce menjadi salah satu alternatif yang paling menarik bagi konsumen untuk berbelanja secara fisik. Bagi pelaku usaha, e-commerce dianggap menarik karena tidak memerlukan modal yang besar untuk membeli atau menyewa tempat usaha, pasar yang besar karena internet dapat diakses oleh para konsumen dari seluruh dunia, dan keuntungan-keuntungan lainnya (Desiani et al., 2019). Berdasarkan uraian pendahuluan diatas, adapun tujuan penelitian ini yaitu mengetahui aspek perlindungan konsumen terhadap transaksi bisnis elektronik, dan mengetahui pengaturan pengawasan transaksi bisnis elektronik dalam menjamin terselenggaranya hak - hak konsumen.

\section{METODE}

Metode penelitian yang digunakan ialah penelitian hokum normatif. Adapun pendekatan penelitian yang digunakan untuk membahas permasalahan penelitian ini adalah pendekatan perundangundangan dan pendekatan konseptual, dengan menggunakan induktif guna mendapatkan dan menemukan kebenaran obyektif. Sumber bahan hukum primer yang digunakan Kitab UndangUndang Hukum Perdata, Undang - Undang Perlindungan Konsumen, Undang - Undang Perdagangan, Undang - Undang ITE, Peraturan Pemerintah Penyelenggara Sistem dan Transaksi Elektronik, Peraturan Pemerintah Perdagangan Melalui Sistem Elektronik. Serta ada pula sumber bahan hukum sekunder seperti jurnal, buku, literature, ensiklopedia dan sebagainya. Teknik pengumpulan data melalui metode pencatatan bahan hukum serta mengumpulkan referensi yang digunakan. Analisis data menggunakan interpretasi hukum secara sistematis dan argumentasi hukum berdasarkan logika deduktif.

\section{HASIL DAN PEMBAHASAN}

\section{Aspek Perlindungan Konsumen dalam Transaksi Bisnis E-Commerce}

Perlindungan Konsumen ialah bagian yang tak terpisahkan dari kegiatan bisnis yang sehat. Keseimbangan perlindungan hukum dalam kegiatan bisnis yang sehat antara pembeli, penjual dan pemerintah, tidak adanya perlindungan yang seimbangan menimbulkan pembeli berada pada posisi yang lemah. Lebih-lebih apabila produk yang diciptakan oleh penjual adalah jenis produk yang 
sedikit, penjual dapat menyalahgunakan posisinya yang monopolistis tersebut. Hal itu tentu saja akan merugikan pembeli (Miru, 2011). Perlindungan ialah hak yang didapatkan masyarakat yaitu berupa hak untuk memperoleh keamanan serta kenyamanan, hingga rakyat merasa aman. Karena posisi konsumen yang lemah maka wajib mendapatkan perlindungan oleh hukum. Kelemahan konsumen dalam hal melaksanakan transaksi elektronik dapat ditinjau melalui terjadinya wanprestasi dalam pemenuhan kewajiban penjual sebagai produsen. Tindakan dari pemerintah melakukan pencegahan atau pun penanggulangan permasalahan yang akan terjadi maupun yang telah terjadi menjadi salah satu tugas penting yang wajib dilaksanakan oleh pemerintah.

Aspek perlindungannya dengan cara mempertahankan hak-hak konsumen terhadap gangguang pihak lain. Agar meningkatkan kesadaran, pengetahuan, kepedulian, dan kemandirian konsumen terutama dalam memilih, menentukan dan menuntut hak-haknya sebagai konsumen. Undang Undang Perlindungan konsumen dituju untuk menciptakan sistem perlindungan bagi konsumen yang mengandung unsur kepastian hukum dalam keterbukaan infomasi, sehingga dapat tumbuhkan sikap yang jujur dan bertanggungjawab dalam menghasilkan barang dan/atau jasa yang berkualitas yang dapat menjamin kelangsungan usaha, kenyamanan, keamanaan dan keselamatan konsumen. Ada beberapa asas-asas dalam perlindungan konsumen yaitu asas manfaat, asas keadilan, asas keamanan dan keselamatan, asas keseimbangan, asas kepastian hukum.

Perkembangan transaksi bisnis elektronik pada Indonesia sangat dibutuhkan perlindungan serta pengaturan guna menciptakan kesejahteraan dalam transaksi bisnis. Pemerintah mengeluarkan sebuah aturan yaitu Undang-Undang nomor 7 tahun 2014 tentang Perdagangan merupakan dasar hukum penyelenggaraan Peraturan Pemerintah PMSE dan konsumen dalam perdagangan melalui via elektronik. Dalam perdagangan melalui sistem elektronik pihak-pihak yang bersangkutan sama saja seperti pada pedagangan konvensional, yang berbeda hanya tidak bertatapmuka langsung dengan para penjual dan pembeli. Dalam Undang-Undang ITE dan PeraturanPemerintah PSTE transaksi bisnis ini dilakukan menggunakan komputer, jaringan komputer, dan/atau media elektronik lainnya. Dalam Undang-Undang Perlindungan Konsumen hak dan kewajiban konsumen terdapat pada Pasal 4 dan 5, serta hak dan kewajiban pelaku usaha pada Pasal 6 dan 7. Pasal- pasal tersebut sudah sangat jelas mengatur mengenai kedudukan pelaku usaha dan konsumen. Demi menciptakan keharmonisan dalam suatu perdagangan maka perlunya ada pengawasan dari pemerintah sekaligus sebagai negara modern yang sejahtera.

Kemudian terkait hal ini terhadap larangan iklan yang menyesatkan konsumen maupun yang mengelabui, seolah-olah produk dan/atau jasa yang diusulkan menyandang kondisi yang layak akan tetapi pada kenyataannya tidak (Nasution, 2001). Opini yang terdapat pada sebuah produk merupakan sebuah unsur yang dapat membuat sebuah ketertarikan oleh pembeli terhadap produk yang akan ditawarkan. Dalam hal pembuatan opini pada setiap kemasan maupun brosur pada produk atau pun jasa dapat memperhitungkan fakta yang dimiliki oleh produk atau jasa tersebut.

Pengawasan oleh pemerintah yang mendapatkan legitimasi melalui pengaturan perundangundangan terhadap pelaku usaha dalam menjalankan aktivitas bisnisnya, adalah bentuk campur tangan Negara dalam urusan kesejahteraan rakyatnya, sekaligus sebagai ciri dari Negara kesejahteraan modern (Hamid, 2017). Pengawasan Pemerintah dalam hal ini dapat mencegah timbulnya tindak pidana penipuan dalam perdagangan elektronik yang dapat diketahui bahwa tindak pidana penipuan merupakan kejahatan yang sangat utama pada suatu perdangan elektronik maupun tradisional.

Undang-Undang Perlindungan Konsumen belum secara jauh mengatur transaksi bisnis $e$ commerce apabila terjadinya sengketa. Pada PeraturanPemerintah PMSE sudah diaturnya mengenai penyelesaian sengketa bisnis e-commerce yang terdapat pada Pasal 72 Bab XV. ODR (Online Dispute Resolution) merupakan penyelesaian sengketa yang menggunakan fasilitas teknologi dalam penyelesaian sengketa para pihak. Dalam hal ini menggunakan negosiasi, mediasi, arbitrase, dan atau kombinasi. Penyelesaian sengketa ini merupakan penyelesaian sengketa diluar pengadilan (non litigasi). Penyelesaian sengketa ini dikategorikan sebagai ADR (Alternative Dispute Resolution). ODR dapat merubah pandangan yangtradisional menjadi teknik yang inovatif dan teknologi pada prosesnya. Jika terjadi kejahatan dalam e-commerce maka itu sudah masuk dalam ranah pidana, jadi ketentuan perundangan-undangan di Indonesia sudah mengaturnya dalam Undang-Undang ITE yaitu pada Pasal 30 serta hukumannya terdapat pada Pasal 46.

Pada penyelesaian sengketa manfaat pengadilan banyak terdapat kritikan dari masyarakat yang pencari keadilan. Secara umum kritikan itu berupa adalah pengadilan sangat lambat dan mahal, 
hakim berpengetahun generalis, publisitas serta putusan pengadilan menempatkan posisi para pihak sebagai the winner dan the losser tidak win-win solution (Harahap, 1997). Penyelesaian sengketa melalui proses pengadilan dipandang tidak efisien sebab dalam proses peradilannya memiliki banyak kendala dalam hal pengajuan serta pengumpulan barang bukti. Selain itu, dalam pandangan masyarakat yang memiliki sengketa mengenai penipuan yang dilakukan dalam perdangan elektronik para pihak lebih condong keranah negosiasi dalam menyelesaikan permasalahan.

Sengket e-commerce merupakan sengketa yang cenderung terjadi berkaitan dengan masalah harga, kualitas barang dan jangka waktu pengiriman. Produk yang menjadi sebuahobyek sengketa apabila jumlah harga atau kuantitasnya terlalu minim, pihak yang terkait tidak perlu orang ketiga dalam penyelesainnya. Hal ini wajar mengingat biaya yangharus dikeluarkan untuk membayar jasa orang ketiga sangatlah lebih besar dari obyek sengketanya. Pengimplementasian ODR sedang menyandang beberapa kendala dan permasalahan yang perlu dilalui. Salah satunya ialah tak ada pengaturan spesifik mengenai ODR. Alat bukti yang sah berupa dokumen elektronik masih menjadi perdebatan beberapa pihak. Budaya masyarakat Indonesia juga menjadi permasalahan yaitu belum secara penuh dapat lepas dari budaya konvensional untuk bertemu langsung secara fisik. Salah satu kendala terekait penerapan ODR ketersediaan infrastruktur teknologi informasi.

\section{Pengaturan Pengawasan Transaksi Bisnis E-Commerce dalam Memenuhi Terselenggaranya Hak-Hak Konsumen}

Transaksi bisnis elektronik dapat seimbanga melalui pengawasan yang tegas dalam penerapannya. Fungsi pengawasan Undang - Undang Perdagangan, belum sepenuhnya diatur dengan jelas mengenai perdagangan e-commerce, sebab fungsi pengawasan pada Undang - Undang Perdagangan hanya pada pedagang umum bukan pada transaksi bisnis elektronik yang mengandung ciri berbeda dengan pedagang tradisional. Perdangan elektronik cenderung dipandang lebih mudah dalam proses jual beli serta produk yang ditawarkan memiliki harga dan promo yang lebih menarik dibandingkan dengan perdangan tradisional yang masih sangat minim proses penawaran barang dagangan.

Kelemahan pada fungsi pengawasan dapat menjadi kesempatan pihak-pihak guna melakukan kecurangan didalamnya. Seperti halnya masalah Standarisasi yang biasa disebut SNI (Standar Nasional Indonesia). Karena mudahnya di iming- imingi harga yang murah karena konsumen sendiri lebih cepat tergiur dengan harga murah tanpa memperhatikan kualitas produk yang akan didapat. Hal ini bisa menjadi kesempatan untuk importir yang memiliki niat buruk agar dapat mencurangi produk yang masuk sebaiknya mentaati standarisasi yang sesuai SNI, melalui transaksi $e$-commerce produk non SNI sangatlah mudah diterima dalam masyarakat. Dalam Ayat (3) Pasal 100 Undang-Undang Perdagangan telah memberikan batasan-batasan mengenai pokok - pokok pengawasan pada perdangan ini.

Kementrian Perdagangan (Kemendag) selaku pembina sektor perdagangan menyatakan bahwa produk harus memenuhi SNI baik perdagangan secara konvensional maupun perdagangan transaksi elektronik, maka dinyatakan produk yang diperjual sudah memenuhi ketentuan. Pada Pasal 2 ayat (1) Permendag nomor 73/M-Dag/Per/9/2015 menyatakan mengenai tata cara pendaftaran, metode pengujian, pengawasan, penghentian, serta penarikan barang. Pendaftaran barang memiliki tujuan mengenai keberadaan serta proses kelayakan produk itu sendiri sehingga dalam peredarannya produk tersebut dapat memaksimalkan pemanfaatnya bagi pembeli. Dalam penarikan suatu produk, dapat dinyatakan bahwa produk tersebut tidak layak untuk diperdaganggkan, hal ini dapat menyangkut mengenai keselamatan pembeli.

Dari ketentuan-ketentuan pada peraturan perundang-undangan diatas terihat pemerintah sangatlah memperhatian perlindungan konsumen di Indonesia.Pihak yang memiliki niat buruk dalam memanfaatkan transakasi elektronik dapat dengan mudah memanfaatkan situasi sebab produk dapat dengan mudah keluar masuk melalui pihak produsen dengan cara penjualan. Kecurangan yang timbul dapat menyebabkan kerugian dari pihak pembeli dan dapat menimbulkan wanprestasi karena tidak terpenuhnya hak - hak yang didapat oleh pembeli secara tidak langsung melalui transaksi elektronik.

Terkait dengan data informasi pelaku usaha wajib terdaftar sesuai yang dikatakan pada Pasal 65 Undang-Undang Perdagangan yang telah diatur dalam Ayat (1) Pasal 10 dan kemudian ayat (1) Pasal 15 Undang-Undang ITE. Terkait dengan sertifikasi ditegaskan dalam Pasal 41 Peraturan Pemerintah PSTE. Proses pemberian sertifikat keandalan dilaksanakan melalui audit atau 
pemeriksaan yang dikerjakan sebelum sertifikasi diberikan, setelah terpenuhinya persyaratan yang diwajibkan ke penjual menjadi bukti bahwa penjual dapat melakukan transaksi elektronik yang diberikan oleh lembaga sertifikasi keandalan.

Identitas merupakan salah satu sarana yang penting yang wajib dimiliki oleh penjual mapun pembeli yang diatur pada Undang-Undang Perdangan. Perizinan usaha bagi pelaku usaha ecommerce sudah diatur pada Pasal 15 PeraturanPemerintah PMSE. Yang dimasukkan dalam daftar prioritas pengawasan hanya yang terkena sanksi administratif, kepada pelaku usaha yang tidak melakukan perbaikan setelah diberikan surat peringatan tertulis ketiga. Dalam proses pemberian sanksi tahap awal dapat berupa pemberian surat peringatan kepada penjual/produsen suatu produk hingga dapat berupa pembekuan izin usaha yang dimiliki oleh produsen/penjual sehingga penjual tidak dapat mengedarkan produk yang dimilikinya.

Pada Pasal 29 Undang-Undang Perlindungan Konsumen menjalankan fungsi pembinaan dan pengawasan atas barang-barang yang diperjualbelikan. Hak yang diterima oleh konsumen harus sesuai dengan asas keadilan dan keseimbangan serta tidak mengesampingkan kepentingan produsen guna menciptakan keharmonisasian dalam transaksi jual beli. Hak - hak yang dimiliki konsumen dan produsen tertuang secara gentleman aggreman yang dilakukan berdasarkan asas kepercayaan. Hak Produsen dalam hal ini dapat dilihat melalui pembayaran yang dilakukan oleh pembeli serta bukti dari hasil pembayaran yang dilakukan.

Terkait dengan pengawasan telah diatur dalam Pasal 30 Undang-Undang Perlindungan Konsumen, dalam pasal tersebut fungsi pengawasan banyak menitikberatkan masyarakat, dibandingkan dengan peran pemerintah. Kesadaran masyarakat yang minim melalukan tindakan yang preventif dapat menyulitkan, seringnya menyikapi dengan masabodo apabila terjadinya kesulitan, serta bahkan apabila sudah terjadi persoalan yang misalnya keracunan suatu makanan maka barulah bertindak untuk melaporkan kepada pihak yang berwenang. Hanya pihak LPKSM (Lembaga Perlindungan Konsumen Swadaya Masyarakat) yang dapat melaksanakan tugas pengawasan pada Pasal 30. Pada Pasal 9 Peraturan Pemerintah nomor 58 tahun 2001 mengenai Pembinaan dan Pengawasan Penyelenggaraan Perlindungan Konsumen menyangkut bentuk pengwasan yang masyarakat lakukan. Serta dalam Pasal 78 Peraturan Pemerintah PMSE juga menegaskan mengenai peran pemerintah dalam pengawasannya. Secara bersamaan pengawasan perlindungan konsumen dilakukan oleh pemerintan, seluruh rakyat serta LPKSM melihat banyaknya jenis barang juga jasa yang beredar di pasar.

\section{SIMPULAN DAN SARAN}

\section{Simpulan}

Bentuk pengawasan yang terdapat pada Undang-Undang Perdagangan dan Undang-Undang Perlindungan konsumen belum cukup untuk perdagangan pada e-commerce, maka dari itu munculah PeraturanPemerintah PMSE yang membahas mengenai pembinaan dan pengawasan transaksi elektronik. Pengawasan yang dilakukan oleh pemerintah dalam bentuk Undang - Undang Perlindungan Konsumen yang dapat mencegah terjadinya wanprestasi tindak penipuan serta menanggulangi permasalahan yang telah terjadi mengenai transaksi bisnis elektronik. Selanjutnya pelaksanaan transaksi elektronik harus sertai dengan pengawasan dalam setiap penerapannya, guna mewujudkan keharmonisasian dalam perdagangan e-commerce. Kemendag sebagai pembinaan bidang perdagangan mengharuskan semua perusahaan memperdagangkan produk dengan memenuhi Standarisasi serta legalitasnya. Tidak luput dari itu, proses pemenuhan persayarat menjadi peran utama dalam hal memenuhi SNI serta kelayakan produk tersebut. Kelayakan produk tersebut guna menunjang hak - hak yang harus didapat oleh pembeli dari penjual atas penjualan produk tersebut.

\section{Saran}

1. Pada penggunaan ketentuan peraturan perundang-undangan, tentunya agar lebih efektif dengan melaksanakannya lebih extra, serta masyarakat juga harus lebih cermat dalam berbelanja pada media elektronik sebab ini sangatlah berbeda dengan perdagang secara konvensional.

2. Untuk meminimalisir terjadinya kecurangan didalam perdagangan e- commerce perlunya penindakan yang tegas dari pemerintas sendiri, serta lebih memperhatikan dengan menyediakan suatu sistem yang efesien dalam mengawasi pelaku usaha dan konsumen dalam melakukan transaksi. 


\section{DAFTAR PUSTAKA}

Barkatullah, A. H. (2007). Urgensi Perlindungan Hak-hak Konsumen. Jurnal Hukum, 14(2), 247-270.

Desiani, A., Amirulloh, M., \& Suwandono, A. (2019). Implementasi Asas Itikad Baik dalam Perlindungan Konsumen Atas Pembatalan Transaksi Yang Dilakukan Oleh Situs Belanja Elektronik. Acta Diurnal Jurnal Ilmu Hukum Kenotariatan Dan Ke-PPAT-An, 2(1), 56.

Hamid, A. H. (2017). Hukum Perlindungan Konsumen Indonesia (I). CV.Sah Media.

Harahap, M. Y. (1997). Beberapa Tinjauan Mengenai Sistem Peradilan dan Penyelesaian Sengketa. Citra Aditya Bakti.

Miru, A. (2011). Prinsip-Prinsip Perlindungan bagi Konsumen di Indonesia. Raja Grafindo Persada.

Nasution, A. (2001). Revolusi Teknologi dalam Transaksi Bisnis melalui Internet. Jurnal Keadilan, $1(3), 28$.

Paryadi, D. (2018). Pengawasan E Commerce dalam Undang-Undang Perdagangan dan UndangUndang Perlindungan Konsumen. Jurnal Hukum \& Pembangunan, 48(3), 652.

Sanusi, A. (2010). Efektivitas UU ITE dalam Pengaturan Perdagangan Elektronik. E- Commerce.

Setyawati, D. A., Ali, D., \& Rasyid, M. N. (2017). Perlindungan Bagi Hak Konsumen dan Tanggung Jawab Pelaku Usaha dalam Perjanjian Transaksi Elektronik. Syiah Kuala Law Journal, 1(3), 4664.

Tuela, M. L. (2014). Upaya Hukum Perlindungan Konsumen Terhadap Barang Yang Diperdagangkan. 2(3), 49-55. 